НЗВЕСТИЯ АКАДЕМИИ НАУК ЭСТОНСКОН ССР. ТОМ ХІІІ СЕРИЯ ФИЗИКО-МАТЕМАТИЧЕСКИХ И ТЕХНИЧЕСКИХ НАУК. 1964, № 1

\title{
О ХИМИЧЕСКОМ СОСТАВЕ И МЕТОДИКЕ АНАЛИЗА НЕПРЕДЕЛЬНЫХ УГЛЕВОДОРОДОВ ЛИГРОИНОВЫХ ФРАКЦИИ СЛАНЦЕВОЙ СМОЛЫ
}

\author{
о. ЭИЗЕН, \\ кандидат технических наук \\ C. РАНГ, \\ кандидат химнческих наук \\ ю. ЭИЗЕН
}

Из индивндуальных соединений сланцевой смолы, кроме легкнх ароматнческих углеводородов, содержащнхся в газбензнне камерных печей, могут найтн прнмененне в первую очередь инеющиеся в большом количестве непредельные углеводороды с нормальной цепью. В настоящей работе прнводятся данные о хнмнческом составе непредельных углеводородов фракции сланцевой смолы $150-215^{\circ}$. Работа является продолженнем опублликованных ранее исследований $\left[{ }^{1}\right]$.

Количественное определение индивидуального состава непредельных углеводоро дов во фракцин выше $120^{\circ}$ является весьма сложной задачей, требующей вполне современғой методикн нсследования и большого количества эталонных вешеств. Анализ затруднен большим колнчеством возможных изомеров олефннов (нормальные 1,2,3олефины, изоолефнны, ици - и транс-изомеры, циклоолефины, моно- и днолефины), этим өбстоятельством и обусловлено отсутствне данных о болышинстве нзомерных соедннений. Второй трудностью является относительно высокая неустойчивость непредельных углеводородов и их склонность к изомернзацин.

Для решения вышеуказанной задачи необходимо изучать физико-химические н спектральные показатели индивидуальных олефинов, а тақже методы их анализа и выделения.

Основной задачей методикн, избранной авторами, было разделение весьма сложной нсходной смесн на фракции с постепенно уменьшающимся чнслом компонентов. Затем авторы попыталнсь в узких фракциях с малым числом компонентов ндентифицировать имеющнеся соедннения. Данные об исходной смоле и ее предварительной обработке содержатся в нашнх других работах $\left[^{2}\right]$. Выход фракции $150-215^{\circ}$ из суммарной смолы составлял 5,6\%. Фракцня $150-200^{\circ}$ составляет от количества обесфеноленного бензнна (конец кнпения при $200^{\circ}$ ) 27,5\%. Легкне фракции (конец кнпення прн $215^{\circ}$ ) можно разделять на части в следующих соотношениях: до $67^{\circ}-14 \%$; $67 \div 150^{\circ}-52 \% ; 150 \div 200^{\circ}-25 \% ; 200 \div 215^{\circ}-9 \%$.

Из фракций $150-200^{\circ}$ и $200-215^{\circ}$ непредельные углеводороды выделялись методом элюентной хроматографин. На основе данных хроматографнрования был рассчитан состав фракцнн $150-215^{\circ}$ :

$\begin{array}{lr}\text { парафнновых и нафтеновых углеводородов } & 25,2 \% ; \\ \text { олефнновых углеводородов } & 42,3 \% ; \\ \text { ароматнческих углеводородов } & 23,0 \% ; \\ \text { кнслородных соеднненнй } & 9,5 \%\end{array}$

Олефнновые углеводороды составляют 110 данным группового состава $42,3 \%$ от фракцин $150-215^{\circ}$ 


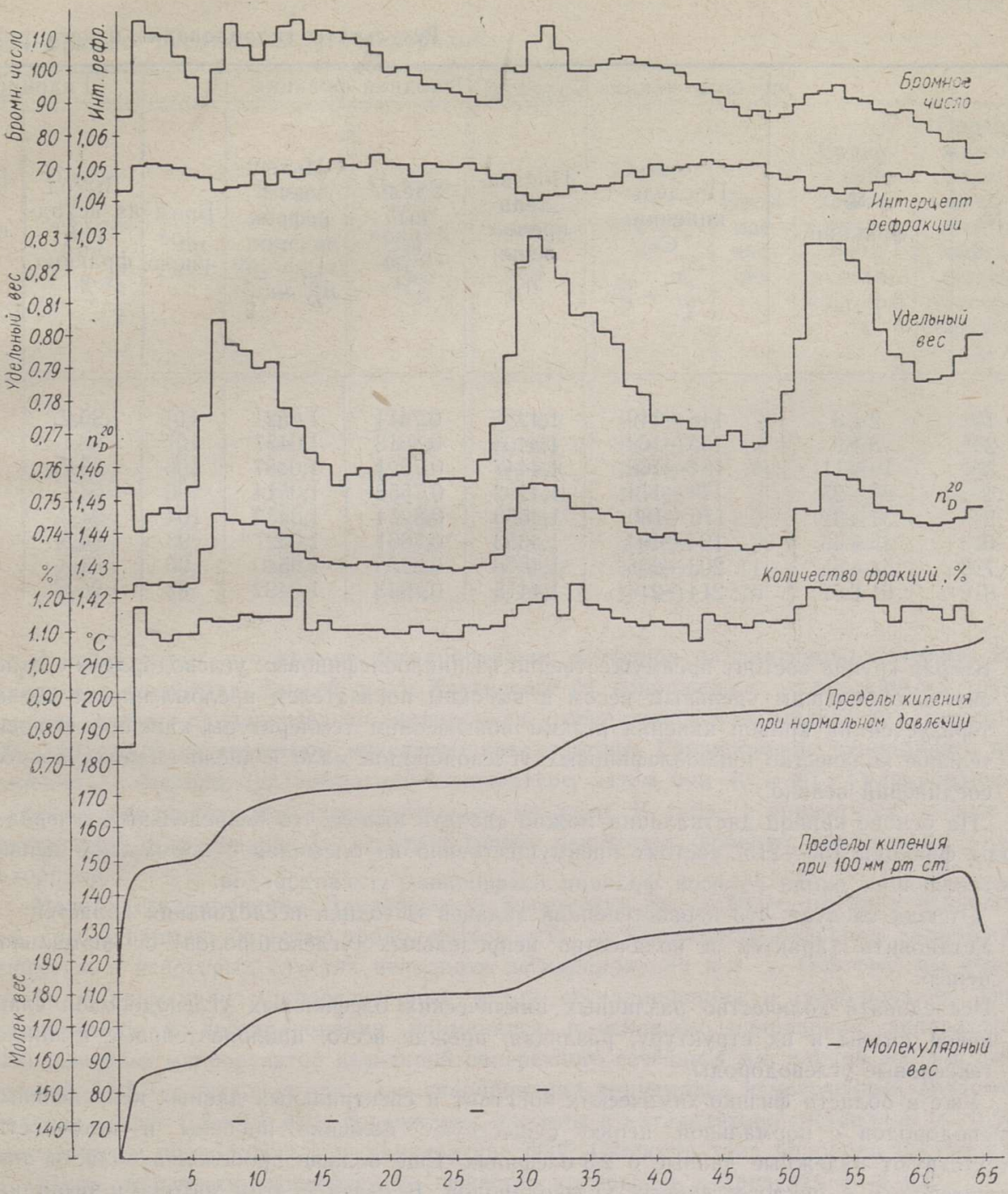

Рис. 1. Фнзнко-химнческие показателн узких фракцнй олефннов фракции $150-215^{\circ}$ бензнна туннельных печей.

Выделенные путем хроматографирования непредельные углеводороды перегонялнсь на узкне фракции в вакууме при остаточном давлении 100 ил рт. ст. Для узких фракцнй определялись физнко-хнмнческие константы и сннмались спектры. Кзучение пзменений физнко-химических констант (рис. 1) позволяет сделать вывод о возможности разделення фракцни олефиновых углеводородов на две основные группы:

1) Первая группа состонт из небольшого числа индивидуальных олефиновых углеводородов. На рис. 1 эта группа характеризуется горизонтальным ходом крнвой кипення с медленным повышением температуры. Горнзонтальный ход кривой кнпения показывает наличие октена-1 и октена-2,3 ..; нонена-1 и нонена-2,3...; децена-1 н децена-2,3 ..; ундецена-1 и ундецена-2,3 .. н, наконец, додецена-1 и додепена-2,3 ... (Под 2,3 ... олефинами подразумевается сумна всех 2,3,4- и т. д. непредельных углеводородов и их цис- и транс-нзомеров.) 
Результаты гидрнрования и дегидрировання

\begin{tabular}{|c|c|c|c|c|c|c|c|c|}
\hline \multirow[b]{2}{*}{ № } & \multirow[b]{2}{*}{$\begin{array}{c}\text { oㅡ } \\
\text { фракции }\end{array}$} & \multirow[b]{2}{*}{$\begin{array}{l}\text { Пределы } \\
\text { кипения, } \\
{ }^{\circ} \mathrm{C}\end{array}$} & \multicolumn{4}{|c|}{ Исходная фракция } & \multicolumn{2}{|c|}{ Гидрированная } \\
\hline & & & $\begin{array}{c}\text { Показа- } \\
\text { тель } \\
\text { прелом- } \\
\text { ления } \\
n_{D}^{20}\end{array}$ & $\begin{array}{c}\text { Удель- } \\
\text { ный } \\
\text { вес } \\
d_{4}^{20}\end{array}$ & $\begin{array}{c}\text { Интер- } \\
\text { цепт } \\
\text { рефрак- } \\
\text { ции } \\
n_{D}^{20}-\frac{d_{4}^{20}}{2}\end{array}$ & $\begin{array}{l}\text { Бром- } \\
\text { ное } \\
\text { число }\end{array}$ & $\begin{array}{c}\text { Выход } \\
\text { из исход- } \\
\text { ной } \\
\text { фракщии, } \\
\%\end{array}$ & $\begin{array}{c}\text { Показа- } \\
\text { тель } \\
\text { прелом- } \\
\text { лення } \\
n_{D}^{20}\end{array}$ \\
\hline $\begin{array}{l}1 \\
2 \\
3 \\
4 \\
5 \\
6 \\
7 \\
8\end{array}$ & $\begin{array}{c}2+3 \\
8+9 \\
10+11 \\
24+25 \\
31+32 \\
45+46 \\
54+55 \\
61+62\end{array}$ & $\begin{array}{l}146-149 \\
155-164 \\
164-168 \\
174-174 \\
176-180 \\
194-194 \\
203-205 \\
214-214\end{array}$ & $\begin{array}{l}1,4256 \\
1,4463 \\
1,4447 \\
1,4292 \\
1,4560 \\
1,4353 \\
1,4572 \\
1,4413\end{array}$ & $\begin{array}{l}0,7471 \\
0,8013 \\
0,7921 \\
0,7556 \\
0,8254 \\
0,7661 \\
0,8265 \\
0,7843\end{array}$ & $\begin{array}{l}1,0521 \\
1,0457 \\
1,0487 \\
1,0514 \\
1,0433 \\
1,0527 \\
1,0540 \\
1,0492\end{array}$ & $\begin{array}{r}114 \\
107 \\
106 \\
96 \\
104 \\
93 \\
96 \\
83\end{array}$ & $\begin{array}{l}95,2 \\
88,1 \\
83,7 \\
64 \\
94,2 \\
94,5 \\
64,3 \\
96,5\end{array}$ & $\begin{array}{l}1,4136 \\
1,4352 \\
1,4328 \\
1,4180 \\
1,4416 \\
1,4246 \\
1,4479 \\
1,4353\end{array}$ \\
\hline
\end{tabular}

2) Вторая группа состоит преимущественно из циклоолефиновых углеводородов с относительно большим удельным весом и высоким показателем преломления, и характеризуется на крнвой кнпения резким повышением температуры кипения. Относительное количество цнклоолефннивых углеводородов мало и число индивидуальинх соединений велико.

На основе кривой дистилляции можно сделать вывод, что непредельные углеводороды фракции $150-215^{\circ}$ состоят преимущественно из олефинов с нормальной целью, составляющих около $2 / 3$ всей фракции олефиновых углеводородов.

Отсюда следует, что первостепенной задачей методики исследования является:

1. установить характер и количество непредельных углеводородов с нормальной цепью.

2. Исследовать количество различных цнклических олефиновых углеводородов сланцевой смолы и их структуру, различая, прежде всего, циклопентеновые и циклогексеновые углеводороды.

Уже в области физико-химических констант и спектральных данных непредельных уғлеводородов с нормальной щепью существуют большие пробелы и неточности. Отсутствуют надежные данные о 2,3-олефинах. Еще больше пробелов в области пнклопентеновых и циклогексеновых углеводородов. В связи с этим авторами былн начаты работы по их синтезу ${ }^{1}$, определению физико-химических констант и изученню спектральных закономерностей. Были синтезированы соединения ряда 1-алкил-циклопентена-1, 1-алкил-циклогексена-1 и 3-алкил-циклогексена-1. В качестве алкилраднкалов были метиловая, этиловая, пропиловая, изопропиловая, бутнловая, пентнловая, изопентиловая, гексиловая и гептиловая группы.

Из-за недостаточного количества имеющихся в наличии эталонных веществ, авторы старались применять методы, с помопью которых оказалось возможным превратить олефиновые углеводороды либо в парафиновые, либо в ароматические углеводороды. Для идентификации последних открылись новые возможности, и получаемые результаты могут оказать существенную помощь в деле выяснення структуры непредельных углеводородов. Так как методы идентификации ароматических углеводородов разработаны более основательно, то прочим методом следует предпочесть метод дегндрировання циклогексеновых углеводородов. Получаемые ароматическне углеводороды определяются хроматографнчески, газохроматографическн или посредством спектрального аналнза. С целью получення необходнмых эталонов были сннтезнрованы 45 алкнлбензолов $\mathrm{C}_{9}-\mathrm{C}_{12} .^{1}$ 


\begin{tabular}{|c|c|c|c|c|c|c|c|c|c|}
\hline \multicolumn{3}{|l|}{ фракция } & \multicolumn{7}{|c|}{ Дегидрированная фракция } \\
\hline $\begin{array}{l}\text { Удель- } \\
\text { ный } \\
\text { вес } \\
d_{4}^{20}\end{array}$ & $\begin{array}{c}\text { Ннтер- } \\
\text { цепт } \\
\text { рефрак- } \\
\text { цнн } \\
n_{D}^{20}-\frac{d_{4}^{20}}{2}\end{array}$ & $\begin{array}{c}\text { Бром- } \\
\text { ное } \\
\text { чнсло }\end{array}$ & $\begin{array}{c}\text { Выход } \\
\text { нз гид- } \\
\text { рнрован- } \\
\text { ной фрак- } \\
\text { ци, \% }\end{array}$ & $\begin{array}{c}\text { Показа- } \\
\text { тель } \\
\text { прелом- } \\
\text { ления } \\
n_{D}^{20}\end{array}$ & $\begin{array}{c}\text { Удель- } \\
\text { ный вес } \\
d_{4}^{20}\end{array}$ & $\begin{array}{c}\text { Ннтер- } \\
\text { цепт } \\
\text { рефрак- } \\
\text { ции } \\
n_{D}^{20}-\frac{d_{4}^{20}}{2}\end{array}$ & $\begin{array}{l}\text { Бром- } \\
\text { ное } \\
\text { чис- } \\
\text { ло }\end{array}$ & $\begin{array}{c}\text { Содер- } \\
\text { жанне } \\
\text { арома- } \\
\text { тиче- } \\
\text { скнх } \\
\text { углево- } \\
\text { дородов, } \\
\%\end{array}$ & $\begin{array}{c}\text { Содер- } \\
\text { жание } \\
\text { пара- } \\
\text { фнно- } \\
\text { вых и } \\
\text { нафте- } \\
\text { новых } \\
\text { углево- } \\
\text { дородов, } \\
\%\end{array}$ \\
\hline $\begin{array}{l}0,7356 \\
0,7950 \\
0,7873 \\
0,7430 \\
0,8066 \\
0,7579 \\
0,8217 \\
0,7753\end{array}$ & $\begin{array}{l}1,0456 \\
1,0377 \\
1,0392 \\
1,0465 \\
1,0383 \\
1,0457 \\
1,0371 \\
1,0457\end{array}$ & $\begin{array}{l}17 \\
39 \\
38 \\
10 \\
36 \\
17 \\
50 \\
28\end{array}$ & $\begin{array}{l}85 \\
84,4 \\
90,2 \\
92,0 \\
88,0 \\
95,5 \\
85,6 \\
86,6\end{array}$ & $\begin{array}{l}1,4135 \\
1,4420 \\
1,4381 \\
1,4188 \\
1,4499 \\
1,4269 \\
1,4496 \\
1,4331\end{array}$ & $\begin{array}{l}0,7353 \\
0,7961 \\
0,7868 \\
0,7440 \\
0,8080 \\
0,7601 \\
0,8106 \\
0,7703\end{array}$ & $\begin{array}{l}1,0459 \\
1,0439 \\
1,0447 \\
1,0468 \\
1,0459 \\
1,0468 \\
1,0443 \\
1,0480\end{array}$ & $\begin{array}{r}2 \\
4 \\
6 \\
6 \\
9 \\
8 \\
11 \\
10\end{array}$ & $\begin{array}{r}3 \\
20 \\
16 \\
5 \\
18 \\
8 \\
18 \\
9\end{array}$ & $\begin{array}{l}97 \\
80 \\
84 \\
95 \\
82 \\
92 \\
82 \\
91\end{array}$ \\
\hline
\end{tabular}

В связи с тем, что прямое дегидрирование олефинов на платиново-железном катализаторе по методу Ландсб́ерга и Казанского [3] сопряжено с определенными трудпостямн, авторы предварительно гидрировали углеводороды в автоклаве при давлении 100-120 к2/ $\mathrm{cm}^{2}$ на скелетном никелевом катализаторе. Гидрирование проводилось постепенно - сначала при комнатной температуре, затем при 40 и $80^{\circ}$. Гидрированные олефнны дегидрировались вышеназванным методом. В табл. 1 приводятся данные 0 результатах гидрнрования и дегидрирования некоторых фракций олефиновых углеводородов.

Метод дегидрирования Ландсберга и Қазанского не свободен от ряда недостатков, как, например: большая продолжительность, необходимость большого количества вещества, в некоторых случаях неполнота дегидрирования и т. д. Поэтому мы выработали и применяли микрореакторный метод дегидрирования и гидрирования. При глдрировании и дегидрированин применялся в основном одинаковая аппаратура. Использовался микрореактор величиной поперечного сечения 4 м.м, длиной 300 мм, вмещавший $1-1,5$ г катализатора. Для гидрирования применялся измельчешный диатомит (величина зерен $0,2-0,4$ мм); содержание платины в катализаторе состав.ляло $5-10 \%$. Гидрнрование проводилось при температуре $200^{\circ}$. Скорость тока водорода составляла $60 \mathrm{~m} /$ мин. Количество исследуемого вешества колебалось в пределах $3-8 \mu л$.

Дегидрирование происходило на платиновом катализаторе в токе гелия при температуре $325-350^{\circ}$.

В установке исследуемое вещество проходило вместе с газом-носителем через реактор, после чего поступало в хроматографическую колонку, где происходило разделение компонентов катализата. Такая методика позволяет в течении одной операции проводить реакцию и ндентифицировать соединения.

Методом микрореакторного гидрирования и дегидрирования исследовались все 65 фракций олефиновых углеводородов. На основе полученных результатов можно определить индивидуальный состав циклогексеновых углеводородов. Открытым остаетсл только вопрос о положении двойной связи по отношенню $\mathrm{K}$ алкильной группе. Наличие данных о времени удерживания циклопентановых углеводородов позволяет сделать заключение н о соединениях циклопентенового ряда.

Сопоставление результатов определения олефиновых углеводородов с нормальной депьо как с методом гидрирования и дегидрирования узких фракций, так и с методом определения состава суммарной фракции олефиновых углеводородов $150-215^{\circ}$,

\footnotetext{
Синтез проводили паучные сотрудники В. Қаск, И. Пыдер и $Э . У_{\text {ск. }}$
} 
указывает на согласне этих данных. Результаты, полученные непосредственно путем газохроматографнческого метода, несколько завышены. Однако, отказаться от этого метода нельзя, так как на основе этого метода определяются н-парафнновые углеводороды, 1-олефнны, а также 2,3-... олефнны. Результаты определения разлнчнымн методами прнведены в табл. 2.

Из данных таблицы нанболее близкими к истинным являются данные третьей графы. Они весьма близки к данным аналнза суммарной фракцин. Результаты определения. циклогексеновых углеводородов различными методами приведены в табл. 3.

Таблица 2

Таблица 3

Содержание (в \%) нормальных углеводородов в олефиновой фракции $150-215^{\circ}$, определенное различными методами

\begin{tabular}{|c|c|c|c|c|c|c|}
\hline \multirow[b]{2}{*}{ 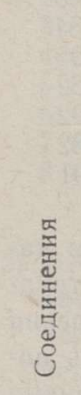 } & \multirow{2}{*}{ 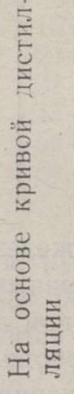 } & \multirow{2}{*}{ 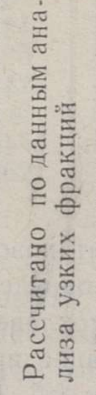 } & \multirow{2}{*}{ 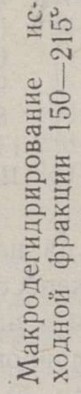 } & \multirow{2}{*}{ 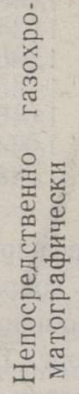 } & \multicolumn{2}{|c|}{$\begin{array}{c}\text { Микрореак- } \\
\text { торное }\end{array}$} \\
\hline & & & & & 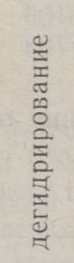 & 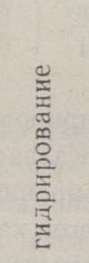 \\
\hline $\begin{array}{l}C_{8} \\
C_{9} \\
C_{10} \\
C_{11} \\
C_{12}\end{array}$ & $\begin{array}{r}- \\
8 \\
27 \\
18 \\
12\end{array}$ & $\begin{array}{r}0,31 \\
7,35 \\
23,77 \\
18,29 \\
10,17\end{array}$ & $\begin{array}{r}0,2 \\
7,6 \\
25,3 \\
18,0 \\
7,8\end{array}$ & $\begin{array}{r}0,5 \\
8,9 \\
25,6 \\
22,8 \\
11,7\end{array}$ & $\begin{array}{r}0,3 \\
7,1 \\
22,0 \\
17,0 \\
9,3\end{array}$ & $\begin{array}{r}0,3 \\
6,2 \\
21,0 \\
17,8 \\
10,4\end{array}$ \\
\hline Bcero & 65 & 59,89 & 58,9 & 69,5 & 55,7 & 55,7 \\
\hline
\end{tabular}

Содержание циклогексеновых углеводородов в некоторых фракциях, определенное макро- и микрореакторным методом дегидрирования

Определение нндивидуального состава высших олефиновых углеводородов непосредственно методом газохроматографин связано с большими трудностями. Из литературных данных о газохроматографическом анализе олефиновых углеводородов следует, что уже о разделении монооле финов $\mathrm{C}_{6}-\mathrm{C}_{8}$ опубликовано весьма мало работ, а разделению олефинов $\mathrm{C}_{9}-\mathrm{C}_{12}$ до конща 1961 года вообще не посвящено ни одной систе-

\begin{tabular}{|c|c|c|c|}
\hline \multirow[b]{3}{*}{ 으 фракцин } & \multicolumn{3}{|c|}{$\begin{array}{c}\text { Содержание щикло } \\
\text { гексеновых угле- } \\
\text { водородов, \% }\end{array}$} \\
\hline & \multicolumn{2}{|c|}{$\begin{array}{l}\text { классиче- } \\
\text { ским макро- } \\
\text { дегидриро- } \\
\text { ванием [?] }\end{array}$} & \multirow{2}{*}{ 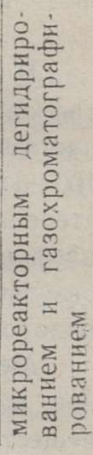 } \\
\hline & 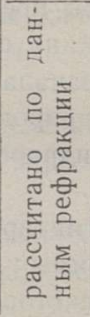 & 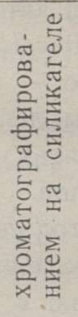 & \\
\hline $\begin{array}{c}2+3 \\
8+9 \\
10+11 \\
24+25 \\
31+32 \\
45+46 \\
54+55 \\
61+62 \\
\text { Исходная } \\
\text { смесь } \\
150-215^{\circ}\end{array}$ & $\begin{array}{r}0 \\
11 \\
8 \\
1 \\
15 \\
3 \\
3 \\
0\end{array}$ & $\begin{array}{r}3 \\
20 \\
16 \\
5 \\
18 \\
8 \\
18 \\
9\end{array}$ & $\begin{array}{r}3 \\
19 \\
13 \\
3 \\
22 \\
7 \\
18 \\
5\end{array}$ \\
\hline
\end{tabular}

матической исследовательской работы. Из-за большого числа возможных индивидуальных соединений разделение неполно, нехватает также данных о калибровке. В случае широкой фракции $150-215^{\circ}$ нельзя получить методом газохроматографии сколько-нибудь надежных данных о содержании олефиновых углеводородов. Лучшие результаты дает анализ узких фракций, при этом можно проследить изменение количества исследуемых индивидуальных соединений и их групп в соответствии с изменением температурных пределов фракций. Несмотря на то, что газохроматография является одним из наиболее эффективных применяемых в настоящее время современных методов разделения органических соединений, добиться с ее помощью полного разделения индивидуальных непредельных углеводородов, даже в случае узких фракций, до снх пор не удалось.

В настоящей работе в качестве неподвижной фазы был использован полиэтиленгликоль фнрмы Мерк (молекулярный вес 4000), кроме того прнменялись $\beta$-, $\beta$-тиоднпропионнтрил, днфеннлформамид н другие синтезированные нами стационарные фазы. 
Длина колонок 6 м, внутренний диаметр 4 мм. Температура $150^{\circ}$, скорость потока во-

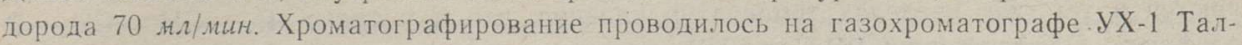
линского завода измерительных приборов.

Из данных непосредственного газохроматографического анализа узких фракций следует, что в непредельных углеводородах могут быть выделены олефины с нормальной цепью, состав.тящие 59-65\% от всех непредельных углеводородов (см. табл. 4). Олефины с нормальной цепью обуславливают появление на газохроматограмме трех пиков. Первый пик характеризует наличие преимущественно 1-олефинов с некоторыми примесями. Второй и третий пики обусловлены наличием иис- н транс-изомеров 2- и 3- ... олефинов. Например, присутствие в исследуемой смесн гептена-1, -2 и -3 обуслав ливает появление на хроматограмме трех пиков:

первый с нанменышим временем удержнвания, вызванный прнсутствием гептена-1 I транс-гептена-3; второй обусловлен наличием транс-гептена-2 и цис-гептена-3 и, наконец, третий ник вызван присутствием чис-гептена-2. Отдельной группой ндентифицируются на газохроматограммах нормальные парафины, как нонан, декан и т. д., попавшие во фракции олефиновых углеводородов при элюентном хроматографировании.

Транс-2,3-... кзомеры олефинов с нормальной структурой концентрируются в газохроматографическую фракцию, выделяющуюся перед фракцией, обогашенной цис-изомерами однонменных олефинов. Как в дальнейшем будет показано, эти данные согласуются с результатами инфракрасного спектрального анализа.

Прямой газохроматографический анализ циклопентеновых и циклогексеновых углеводородов возможен лишіь постольку, поскольку имеются литературные данные о временах удерживания или синтезиряванные эталонные углеводороды. Неполнота этих материалов делает вполне обоснованным определение циклогексеновых углеводородов методом дегидрирования, описанным выше.

Найболее богатую ннформацию при спектральном определении олефиновых угле. водородов дают инфракрасные спектры.

При рассмотрении инфракрасных спектров в очередном порядке фракций с прослеживанием хода изменений различных олефиновых групп с ростом пределов кнпения выясняется следующее:

1) Обусловленные олефиновыми связями максимумы ннфракрасных спектров характеризуются преимущественно следующими волновыми числами: $1640,990,910,965$, 890,675 - $730 \mathrm{~cm}^{-1}$, которым отвечают валентные колебания связи $>\mathrm{C}=\mathrm{C}<$, группнровки $\mathrm{RCH}=\mathrm{CH}_{2}, \mathrm{RCH}=\mathrm{CHR}$ транс-и цис-олефины и непредельные связи $\mathrm{RR}^{\prime} \mathrm{C}=\mathrm{CH}_{2}$ u $\mathrm{RR}^{\prime} \mathrm{C}=\mathrm{CHR}$.

2) Основной непредельной группой во фракции 150-215 сланцевой смолы яв ляется транс- $\mathrm{R}-\mathrm{CH}=\mathrm{CH}-\mathrm{R}$, которая присутствует непрерывно во всем указанном пределе температур. Количественные максимумы этой группировки находятся в пределах кнпения $\boldsymbol{H}-2,3-\ldots$ децена, $\boldsymbol{H}-2,3-\ldots$ ундецена и $\boldsymbol{H}-2,3-\ldots$ додецена. Максимум представлен также в так называемых переходных фракциях кривой кипения, содержащих в большом количестве циклических олефинов. Следовательно, и части циклических непредельных углеводородов дают сильно выраженные максимумы в областн $965 \mathrm{CM}^{-1}$.

3) Значительно слабее представлены максимумы циис-олефинов $\mathrm{R}-\mathrm{CH}=\mathrm{CH}-\mathrm{R}$ в пределах кипения $150-215^{\circ}$. При этом максимум цис-олефинов всегда следует за максимумом транс-олефинов. Отсюда следует, что в обшем транс-олефины сланпевой смолы кипят ниже, чем одноименные иис-олефины. Не исключено, что наряду с иисолефннами с нормальной цепью в соответствующих фракциях присутствует известное количество никлоолефннов с цис-структурой.

4) Второй олефиновой группировкой, сильно представленной в сланцевой смоле, являются олефины типа $\mathrm{R}-\mathrm{CH}=\mathrm{CH}_{2}$. Максимумы 1-олефинов расположены в области волновых чисел 910 и $990 \mathrm{~cm}^{-1}$. На кривой кипения $150-215^{\circ}$ имеются четыре максимума непредельных олефинов, отвечающие точкам кипения нонена-1, децена-1. ундецена-1 и додецена-1. Во фракциях (на рис. 1) $20-32,46-52$ и 65 , согласно данным инфракрасных спектров, олефины-1 отсутствуют. С этим согласуются также газохроматографнческие данные. 
5) Очень слабо предславлены олефины $\mathrm{RR}_{1} \mathrm{C}=\mathrm{CH}_{2}$; слабые макснмумы наблюдаются в тех же пределах температур кнпения, что н у транс- $\mathrm{R}_{1}-\mathrm{CH}=\mathrm{CH}-\mathrm{R}$ олефинов. Олефины типа $\mathrm{RR}_{1} \mathrm{C}=\mathrm{CHR}$, дающне максимумы в пределах волновых чисел $810-840 \mathrm{~cm}^{-1}$, представлены в небольшом количестве в областях температур кипения циклоолефинов. Тем самым указанные олефины представлены преимущественне

в виде структуры Возможна, конечно, и изоолефнновая структура.

6) Валентное колебание группировки $>\mathrm{C}=\mathrm{C}<$ в области 1640 c $^{-1}$ представлено более сильно в прєделах кипения, отвечающих макснмумам 1-олефинов.

7) Максимумы в области волнового чнсла $725 \mathrm{~cm}^{-1}$, указывающего на прнсутствне длинных углеводородных цепей, выражены во фракциях, где максимально представлены нормальные олефнны.

Максимум $725 \mathrm{~cm}^{-1}$ является наименьшим в области, где представлены количественные максимумы циклоолефиновых углеводородов.

8) Максимум некоторых фракций в областй волнового числа $1710 \mathrm{~cm}-1$ обусловлен наличием группы >CO. Так как в данной спектральной области максимумы олефиновых углеводородов выражены слабо, то можно предполагать, что в ходе процесса исследования последние окислялись под действнем кислорода воздуха. Из имеющихся немногих данных весьма трудно сделать какие-либо заключения, однако, весьма ве роятно, что окислению быстрее всего подвергаются области, содержащие больше всего циклоолефиновых углеводородов.

Результаты обработки обширного материала, полученного при применении указанных методов, помещены в табл. 4, содержащей суммарные данные о химическом составе непредельных углеводородов фракции $150-215^{\circ}$ эстонской сланцевой смолы.

На основе данных табл. 4 можно сделать следующие заключения:

1) Впервые приводится количественный индивидуальный состав и структура непредельных углеводородов более тяжелых фракций сланцевого бензнна. Идентифнцировано с определением химической структуры $70 \%$ от состава концентрата непредельных углеводородов.

2) Аналогично бензину, килящему до $150^{\circ}\left[{ }^{1}\right]$, основную часть фракции и здесь составляют углеводороды с нормальной цепью. По сравнению с 1-олефинами, которые были преобладающими компонентами во фракций сланцевого бензина, кипящей до $150^{\circ}$, в данной фракции преобладают олефины с двойной связью в середине цепи. Больше всего содержится во фракции $150-215^{\circ}$ деценов с нормальной цепью, составляющих $24 \%$ от концентрата непредельных углеводородов.

3) Циклогексеновые углеводороды составляют до $12 \%$ от состава концентрата. По химической структуре идентифицировано $7 \%$ фракции или $60 \%$ количества циклогексенов. Производные циклогексена весьма многочисленны. При этом ни одно индивидуальное соединение особенно не превышает остальных по количеству. Содержание циклогексенов с нормальной цепью значительно превосходит содержание циклогексенов, обладающих изоструктурой в боковых цепях. Из соединений с изоструктурными боковыми цепями были найдены лишь 1-метил-4-изопропилциклогексены и изопропилциклогексены. При этом, изопропилциклогексенов по количеству примерно в 8 раз меньше циклогексенов с нормальной цепью. Среди циклических олефиновых углеводородов наибольшее количество приходится на долю 1-алкил-циклогексенов-1, что согласуется и с термодинамическими закономерностями. Из компонентов с большим содержанием присутствуют пропил-, бутил-, и пентилциклогексены, все примерно в одинаковом количестве. Из более существенных по содержанию компонентов следует еще назвать метилпропил-, метилбутил- и диметилэтилциклогексены. Преобладают положения 1,$2 ; 1,4 ;$ и $1,2,4$, гораздо реже встречаются боковые цепи в положеннях $1,3,5$ и 1,3 .

4) Менее всего идентифицированы цнклопентены. В большом количестве присутствуют 1-бутил-, 1-пентил-, 1-гексилциклопентены-1. Идентифицированная часть составляет лишь $5,1 \%$ от всего количества олефнновых углеводородов. 
Химический состав непредеяьных углеводородов фракцин $150-215^{\circ}$ сланцевой

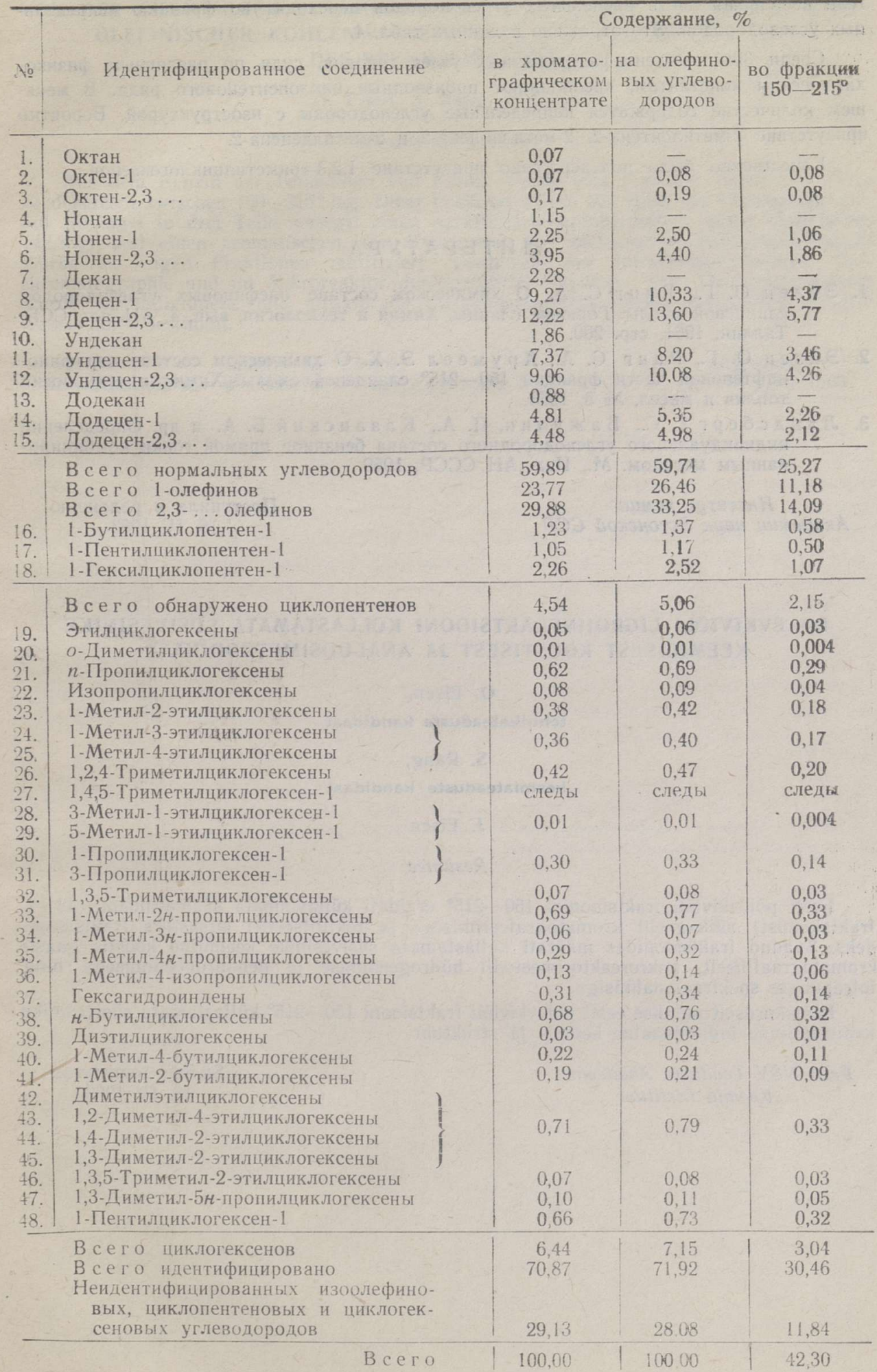


В ходе разделення групп углеводородов путем хроматографнровання на снлнкагеле небольшая часть предельных углеводородов переходнт во фракцню непредельных углеводородов. Это отражено в данных табл. 4.

Среди $30 \%$ нендентифнцнрованных углеводородов, судя по разлнчным фнзнкохимическим константам, преобладают производные цнклопентенового ряда. В мень шем көлнчестве содержатся непредельные углеводороды с нзоструктурой. Вероятно: присутствне 2-метнлоктена-2, 2-метнлнонена-2 н 2-метилдецена-2.

Качественно было подтверждено прнсутствне 1,2,3-трнметнлциклогексенов.

\title{
Л И T E Р А Т Р A
}

1. Эйзен О. Г., Р анг С. А. О хнмическом составе олефнновых углеводородов сланцевой смолы. Горючне сланцы. Химня н технологня, вып. 4, АН Эст. ССР, Таллнн, 1961, стр. 200.

2. Эйзен О. Г., Р анг С. А., Арумеел Э. Х. О химнческом составе парафннонафтеновой части фракцин $150-215^{\circ}$ сланцевой смолы. Химия н технология топлив и масел, № $5,1963$.

3. Л андсберг Г. С., Ба жулин, П. А., К а з ан ки й Б. А. и др. Определенне индивидуального углеводородного состава бензннов прямой гонки комбннированным методом. М., Изд. АН СССР, 1959.

Ннститут химии

Академии наук Эстонской ССР
Поступнла в редакцню

16. IV 1963

\section{POLEVKIVIOLI LIGROIINFRAKTSIOONI KULLASTAMATA SÜSIVESINIKE KEEMILISEST KOOSTISEST JA ANALUUSIMETOODIKAST}

\author{
o. Eisen, \\ tehnikateaduste kandidaat \\ S. Rang, \\ keemiateaduste kandidaat
}

J. Eisen

Resümee

Eesti pōlevkiviōli fraktsioonist $150-215^{\circ}$ eraldati küllastamata süsivesinikud $(42,3 \%$ fraktsioonist) silikageelil kromatografeerimisega ja rektifitseeriti kitsasteks fraktsioonideks. Saadud fraktsioonides määrati küllastamata süsivesinike keemiline koostis gaasikromatograafiliselt, mikroreaktorimeetodil hüdrogeenimise ja dehüdrogeenimisega ning infrapunase spektraalanalüüsiga.

Esmakordselt antakse eesti pōlevkiviōli fraktsiooni $150-215^{\circ}$ küllastamata süsivesinike kvantitatiivne individuaalne koostis ja struktuur.

Eesti NSV Teaduste Akadeemia Keemia Instituut
Saabus toimetusse

16. IV 1963 


\title{
VON DER CHEMISCHEN ZLSAMMENSETZUNG UND DEN ANALYSEMETHODEN OLEFINISCHER KOHLENWASSERSTOFFE DER LIGROINFRAKTION DES BRENNSCHIEFERÖLS
}

\author{
O. Eisen, S. Rang, J. Eisen
}

\section{Zusammenfassung}

Aus dem Benzin der Tunnelöfen von Kiviöli wurde eine Fraktion destilliert, deren Siedebereich $z$ wischen $150-215^{\circ}$ lag. Diese Fraktion wurde mit Hilfe der Chromatographie auf Silikagel in drei Teile zerlegt: einen paraffinisch-naphthenischen, einen olefinischen $(42,3 \%)$ und einen aromatischen. Ein Konzentrat der olefinischen Kohlenwasserstoffe wurde zu engen Fraktionen rektifiziert. Vermittels der Infrarotspektroskopie, Gaschromatographie und im Mikroreaktor durchgeführter Hydrier- und Dehydrierverfahren wurde die individuelle und strukturelle Zusammensetzung dieser olefinischen Kohlenwasserstoffe bestimmt.

Institut für Chemie

der Akademie der Wissenschaften der Estnischen SSR
Eingegangen am 16. April 1963 